Historic, Archive Document

Do not assume content reflects current scientific knowledge, policies, or practices. 



\section{ROCK GARDEN PLANTS}

All plants delivered free.

Quantity prices on all these will be low, so send your want list, stating quantity of each. Price will be made to fit your list, as quantity production is my aim and sales help it, of course.

ASTER PLEIADES-A six-inch mound of small lavender flowers in late August. Blooms first year from even a late planting, perennial and a good increaser. Fine for either indiviaual clumps, edgings or masses. New and good. 50c. $\$ 3$ per doz.

ACHILLEA NANA-Feathery grey green leaved 2 in. creeper that can be walked on as it is os dense and tough. Fills crevices nicely. 25c. \$2 per dozen.

ARENARIA GRANDIFLORA-A selected form from cuttings of a long blooming kind of this 6 in. grassy leaved plant. Mother plant four years old had 600 white blooms in June, and will flower intermittently until frost. Winter foliage like a small phlox subulata. 25c.

ARENARIA VERNA or SAGINA GLABRA-Creeping low over the ground and between cracks in stones. Excellent for the rock garden and between flagstones. My dwarfest creeper for cracks and crevices, not an inch high. Some dampness and shade. Very green foliage and white flowers. 20c. $\$ 1$ dozen.

Golden leaved form of above, liking sun, 50c.

ARMERIA LAUCHEANA-Bright losy red, 3 to 6-in, will succeed in any soil, forming evergreen tufts of bright green foliage. They flower more or less continuously. Very useful in the rockery and border edgings. 20c.

ASCLEPIAS TUBEROSA (Butterfly weed)-Grows about $2 \mathrm{ft}$. high. This beautiful orange milkweed attracts butterflies. It will not complain of drought as it roots deep. Small plants bloom quicker, as larger ones wait a few years. 4 for $\$ 1$. Plant in a group 18 inches apart.

BELLIUM MINUTUM-A dainty miniature that throws out numerous runners and so forms a wide mat, covered in summer with very white absolutely perfect shaped daisies on 1-in. stems. Fine for sunny niches in rockery. 25c. $\$ 1.50$ dozen.

CARYOPTERIS MONGOLIENSIS-Compact grey leaved shrubby 2-in. perennial, with blue flowers in late summer. Roots as it slowly creeps. Aromatic scented leaves, in fact it is like a sage-brush with baseball blue flowers. Likes dry, poor, sunny place. Very rare and blooms first year. Good cut flower, $75 \mathrm{c}$.

DIANTHUS DUNEDIN (alpinus)-Compact ball of shiny green foliage three inches high with large pink flowers in June on stems 1 inch above the foliage. A gem, a seedling that is very easy to grow while Dianthus alpinus, which it resembles, is very difficult here at least. 25c.

DRABA REPENS-Very small leaved fast creeper, with very early yellow flowers. About 2 in. 20 c.

LINARIA AEQUITRILOBA-Very flat creeper, steady bloomer, lavender. Valuable flat creeper for rock niches, hardy, like a quarter size Kenilworth ivy (which is not hardy here). Makes wonderful mats of foliage. 25c.

LITHOSPERMUM CANESCENS-An orange flowered ball about 10 inches across in very early spring. Sun and sand suit it. Collected plants. \$15 per 100.

PHYSOSTEGIA VIVID-Everyone wants autumn flowering plants. This is a much freer, pinker form of the wild Virginia false dragonhead, with solid masses of bright pink. Tolerates damp places. One foot. Ought to be in clumps for best effect. 20c. $\$ 1$ dozen.

YUCCA COLO-MA-A new species of very dwarf habit, small 6 inch rosettes of glaucous-blue foliage, distinct from others, and hardy, 18-in white flower spikes. $\$ 1$.

\section{FRANK W. CAMPBELL}




\section{SEEDS}

Rocky Mountain Seeds in a great mixture of nearly 400 kinds at $25 \mathrm{c}$ per $1 / 4$ ounce. Demand this year does not warrant the expense of listing them separately.

PENTSTEMON EATONI-Brilliant scarlet at a time in early spring when no such color is among my hundreds of plants. Hardly two feet high. Sandy loam and sun suits it best. Seed only. 25c packet.

\section{SEDUM}

Sedums, veronicas, and thymes alone can make the finest of rock gardens, so varied are their characteristics.

ACRE MINUS-An absolutely dwarf sedum acre, quite a bit smaller than the form "minor" which up to now was the smallest available. $\$ 1$.

HYBRIDUM-Prostrate round leaved creeper with very green summer foliage and very red winter foliage, yellow flowers. Winter color in landscaping has been a neglected item. 50c a square foot.

ELLACOMBIANUM-Very red autumn foliage, very green summer foliage in a one foot dense mound, yellow flowers. Spring new growth very attractive. 20c. \$2 doz.

5 good sedums, including above, for $\$ 2$.

\section{VERONICA}

ARMENA-Fine rock garden plant for all around use. Slow creeper wi.h finely cut leaves that always look well. Flax blue $1 / 2$ in. flowers in early spring literally covering the plant, with scattering bloom until frost. Very hardy. Does well in any position seemingly. Hangs neatly. 30c.

FILIFORMIS-Exceedingly fast creeper, evergreen, round leaved, with blue flowers in spring. New and unusually usable, as it does well in sun or shade, wet or dry. Can be walked on same as grass. 25c.

PECTINA'TA-Grey leaved dense creeper like a larger woolly thyme. Rose flowers in spring. Dry, sun. 25c.

TRUE BLUE-A foot high, dark blue, early summer bloomer that blooms again in the autumn often. 25c.

5 good Veronicas, including above, for $\$ 1$.

\section{THYME}

THYMUS ALBA MINOR-Very flat creeper for dry, sunny soil. Fine for stepping stones. Very white flowers. Aromatic foliage. 20c.

THYMUS LANUGINOSUS (WOOLY)-Wooly grey leaved form of above. 20c.

THYMUS NARROW LEAF-A narrow leaf form that hangs nicely from crevices. Mauve flowers. A chance seedling of mine. 25c.

THYMUS MICANS-A round ball of green narrow leaves. Most effective mound shaped plant I have. 3 inches, lavender. New, rare and a gem in any garden. Fine potted plants. 50c.

\section{SIBERIAN IRIS}

Grassy leaved iris. These will stand damper, richer ground than iris Germania. They always bloom just as the German Iris has finished. Very fine for cutting.

EMPEROR, dark blue purple, late, best of the older varieties. 25c.

CAESAR'S BROTHER, a wonderful iris similar to above but darker and of a pansy like finish. Not to be confused with the variety Caesar. $\$ 5$.

KINGFISHER, similar to Emperor but has two more blooms per stem and is open a week longer. $75 \mathrm{c}$.

KINGFISHER BLUE, similar to the light blue Perry Blue, but larger. 50c.

MYBLUE-An early clear dark blue with no purple in standards. A seedling of mine that is so free blooming that it is the best mass I know of. 30c.

\section{SPURIA IRIS}

They are seldom seen and have such graceful, lasting beauty, liking rich, heavy, damp soil. Two to four feet high and stems very stiff. Pick when in bud and they will keep a week or more, everyone will open.

MRS. A. W. TAIT, lavender. 20c.

ORCHROLEUCA (cream with yellow center). 20 c. 